\title{
Junior High School Students' Perception of Classroom Environment and Their English Achievement
}

\author{
Rahmedia Alfi Rahmi \\ Ganesha Operation, Muara Enim, South Sumatra, Indonesia \\ E-mail: minamy_cutez@yahoo.com \\ Chuzaimah Dahlan Diem (Corresponding author) \\ Faculty of Teacher Training and Education, Sriwjaya University \\ Jalan Raya Palembang-Prabumulih, Km. 32, Inderalaya, Ogan Ilir, Sum-Sel, Indonesia \\ E-mail: chuzaidd@gmail.com
}

Received: 01-10-2013

doi:10.7575/aiac.ijalel.v.3n.3p.41
Accepted: 08-01-2014

Published: 01-05-2014

URL: http://dx.doi.org/10.7575/aiac.ijalel.v.3n.3p.41

\begin{abstract}
Classroom environment is different from one school to another. This may lead to students' achievement. This study was aimed at finding out whether the two variables were correlated positively by involving 378 students selected randomly from 55 schools in different sub-districts. The 'What Is Happening In this Class (WIHIC) questionnaire' and an English test were used to collect the data. The findings showed that: (1) there was a positive correlation between classroom environment and students' English achievement; (2) although there was very small contribution of classroom environment (total) to students' English achievement, yet when stepwise method was applied, 'equity' aspect shared the highest contribution to students' achievement, and (3) interestingly, based on gender, there was a significant difference in students' perception of classroom environment but not in their English achievement.
\end{abstract}

Keywords: classroom environment, students' English achievement, ELT

\section{Introduction}

English is one of the international languages most widely used as a means of communication among people in the world and in many aspects of life. Having a good command of English is a must for everyone living in this century. Fortunately, many people from non-English speaking countries have realized the importance of learning this language as early as possible in order to be able to mingle well with other people from various countries and follow the information which spreads and changes rapidly.

Knowing its effect on the international milieu, English becomes a foreign language in several developing countries including Indonesia. In this country, English is considered important to be mastered by its citizens in order to be able to know and disseminate science, technology, culture and arts, and most of all establish relationships with other countries. In Indonesia, English is taught as a compulsory subject from junior high school up to university level, but sometimes the educators also teach English in elementary or even early childhood education. In addition to using this language internationally, Indonesian students also need to learn English because it is tested in the national examination which has certain standard to pass. Junior high school students, in this case, are expected to master the functional level of literacy skills which requires them to be able to communicate in written forms or orally to fulfill their needs (BNSP, 2006). In fact, Yunizar (2011) found that about 1.676 state and private junior high school students in South Sumatera failed in National Examination in 2010. It means that junior high schools in South Sumatera were unsuccessful to reach even the minimum standard score which was 5.5.

Moreover, the average English score at the National Examination in academic year 2009/2010 for senior high schools in South Sumatera showed that the students from science program had 7.41 while those from social program only had 7.01 (Diknas, 2010). The same fact is shown by those in Palembang City; the students from science and social programs respectively achieved the mean score of 7.23 and 7.04 for their English. If these scores are converted into five categories (excellent - 86-100; good-71-85; average - 56-70; poor-41-55; very poor (fail) - 0-40) (FKIP-Universitas Sriwijaya, 2008), it can be said that most senior high school students have obtained average score for their English subject. However, getting the average score in national examination is still questionable because there are still many problems embedded in the process of the examination itself. Purwadi (2011) reported that many students tried to pass the examination by fraud. Unfortunately, this cheating behavior was connived by many headmasters and teachers. This situation was justified by the Indonesian Ministry of Education and the head of National Education Standard Committee (BNSP).

Furthermore, the data from one senior high school in Palembang (SMAN 2, 2011) on students' English achievement also showed similar results, that is, out of 147 twelfth grade students, 2.04\% of them had an A grade (4--excellent), $48.29 \%$ had a B (3--good), 40.14\% had a C (2--average), and still 9.51\% had a D (1--poor). In other words, their mean 
score was about 60.75 . However, this condition seems to be contrary to the A status held by the school for its accreditation. These students should have had above average or good English proficiency because they have studied English at least for 6 years, that is since they were in grade 7 . Having the average score of 60.75 is really unsatisfactory because these students, later on, will continue their study to higher education which requires them to have good English proficiency in order to pass the entrance test.

Another problem in students' English achievement is found in one of the RSBI junior high schools in Palembang (SMPN 1, 2011). It showed that only $20.95 \%$ out of about 160 -ninth graders obtained grade A (excellent) for their final semester examination. Holding the RSBI status, the school required their students to use English everyday either in or out of the classroom with the hope that these students have excellent English competency needed for their future education. Therefore, based on the data above, it can be concluded that students' English achievement in Palembang is still a problem and it needs to be solved.

The unsatisfactory English achievement is certainly caused by many factors which can be divided into internal and external factors (Slameto, 2003, p.54). The internal factors usually come from the students themselves such as low motivation to do better in the subject taught at the school and negative self-concept (Read also Diem, 1988; Diem, 1998; Fitriani, Diem, \& Saripudin, 2007). These factors make the students become less competitive without having any desires to improve themselves. External factors are usually coming from the parents, facilities, economic status, and also classroom environment. Klem and Connell (2004) said that schools which provide good environment are more likely to have students who are involved and attached to their school. In line with this, Miller and Cunningham (2006) also found that classroom environment, which encompasses a broad range of educational concepts, such as physical setting, psychological environment created through social contexts, and numerous instrumentional components related to teacher characteristics and behaviors, is known to be one of the most important external factors.

A good classroom environment must be provided in every school, especially for junior high schools whose students are between 12 and 15 years of age and facing transitional changes from children to middle adolescent and are not only in the process of developing physically, but also psychologically. Sarwono (2006) found that junior high school students tend to look for their identities in the society by interacting more with other friends who have similar characteristics with themselves. They are sometimes in doubt about what they should and should not do, and what they really want. Therefore, a conducive-classroom environment is needed by these students.

In addition, students spend much of their time in schools by interacting among themselves as well as with their teachers. It is not surprising when people say that school has an important influence in students' development because classroom environment and psychosocial interactions can make an improvement in how the students learn and achieve their goals. Based on the studies conducted in Indonesia by Margianti, Fraser, and Aldridge (2001), and in Singapore by Fraser and Chionh (2009) and Goh and Fraser (1998), school and classroom environment themselves are aimed at encouraging and establishing student self-control through a process of promoting positive student achievement and behavior.

Sun-Geun and Hye-Jeong (2002) who did their research to 1.012 students of $10^{\text {th }}$ and $11^{\text {th }}$ grades at one same school district in Seoul, Korea, proved that although there were differences in students' perceptions in terms of gender, the seven subscales in the Korean Classroom Environment Scale (KCES) questionnaire had a significant correlation with students' academic achievement as measured by English achievement test. Based on this result, it can be claimed that classroom environment is a good predictor of students' academic achievement.

The result of the study done by Treagust and Wahyudi (2004) supported the research findings of Sun-Geun and HyeJeong (2002). They conducted a research in the same field of study. Their findings showed that there were significant differences between students' perceptions of the actual and preferred learning environment, with students tending to prefer a more favorable classroom learning environment than the one which they actually experienced.

Gender-related differences in students' perceptions of their learning environment were reported not only by Sun-Geun and Hye-Jeong (2002) but also by several other researchers. Hoang (2008) also explored gender differences in students' perceptions of mathematics learning environment. He concluded that male students had better perceptions of classroom environment and attitudes than female students. This finding is in line with the result of brain-based research done by Gurian and Stevens (2004). They found that a girl's stronger neural connectors and a larger hippocampus provide greater use of sensory memory details in speaking, reading and writing while boys' brains are better suited to symbols, abstractions, and pictures. Consequently, boys generally learn higher math and physics better than girls. Similarly, Kim, Fisher, and Fraser (2000) reported that boys' perceptions of learning environment were different from girls' perceptions. It was reported that boys perceived more teacher support, involvement, investigation task orientation, and equity than did girls.

Based on the reviewed studies above, we felt that it was important to do a survey to find out the existing phenomena about classroom environment as perceived by students themselves and their English achievement. Therfore, this present study highlights the relationship between the two variables and describes the difference between the two variables in terms of students' gender.

\section{Method}

The sample of this study consisted of 378 eighth graders equally chosen based on gender from 55 state junior high schools in 15 sub-districts in Palembang. The schools were chosen based on the types of accreditation they had, which were A, B, and C (BAP-S/M Sumatra Selatan, 2010). 
To measure the students' perception of their classroom environment, a questionnaire invented by Fraser, Fisher, and McRobbie (1996) cited in Khine (2001) and named "What is Happening in this Class (WIHIC)" was used. The instrument was firstly tried out and the reliability of which was 0.94 . Then a general English test randomly taken from the national examination was also administered. It was found that its reliability was 0.85 . According to Khine (2001), the WIHIC questionnaire was intended to measure the psychosocial aspects of the classroom learning environment in various contexts. It consisted of 7 aspects with 8 statements of each and should be answered in 15 minutes. The seven scales are: student cohesiveness, teacher support, involvement, investigation, task orientation, cooperation, and equity. This questionnaire used Likert scales with five categories of points which range from 1 to 5: 1- Almost Never, 2Seldom, 3- Sometimes, 4- Often, and 5- Almost Always. So, the highest possible total score the students could obtain is 280 and the lowest is 56 while for each aspect, the highest possible obtained score is 40 and the lowest is 8 . Meanwhile, the general English test comprising reading, expressions, structure, vocabulary, and reference consisted of 50 multiple choice questions to be answered by the students individually in approximately 55 minutes. If the students could answer all the questions correctly, they would get 100 meaning one item scores 2, but if their answers were all wrong, they would get 0 (zero).

In order to have clear information about the degree of students' English achievement, the scores obtained were categorized into five categories. These categories are as follows: excellent (86-100), good (71-85), average (56-70), poor (41-55) and very poor (0-40) (Fakultas Keguruan dan Ilmu Pendidikan-Universitas Sriwijaya, 2008).

By using SPSS version 17, the data obtained were analyzed to describe frequency, percentage, mean, and standard deviation of the students' perception of classroom environment and their English achievement. Then, to see the correlation of the two variables, Pearson Product Moment Correlation was used. The last step was to use stepwise multiple regression analysis in order to see whether or not there was any contribution of students' perception on classroom environment $t_{\text {total }}$ and which among its seven aspects contributed the most to the students' English achievement.

\section{Results and Discussion}

\subsection{Descriptive Statistics}

\subsubsection{Students' Perception of Classroom Environment and their English Achievement}

The descriptive statistics of the variables, i.e. students' perception of classroom environment and their English achievement are presented in table 1. It can be seen that the mean score and standard deviation of classroom environment total were 185.10 and 29.706 respectively. The mean score and standard deviation for each aspect of classroom environment were 28.56 and 4.735 for student cohesiveness, 25.69 and 6.037 for teacher support, 24.12 and 5.752 for involvement, 22.96 and 6.146 for investigation, 29.82 and 5.355 for task orientation, 25.79 and 7.326 for cooperation, and 28.54 and 6.318 for equity.

Meanwhile, for students' English achievement (SEA), the mean score total $_{\text {was }} 38.23$ with standard deviation of 14.753. Table 1 shows that, only 1 student $(0.26 \%)$ obtained excellent score, 18 students $(4.76 \%)$ had good score, 34 students (8.99\%) obtained average score, 61 students (16.14\%) had poor score, and 264 students $(69.84 \%)$ had very poor score.

Table 1. Descriptive Statistics Summary of Students' Perception of Classroom Environment (SPCE) and their English Achievement (SEA) $(\mathrm{N}=378)$

\begin{tabular}{|c|c|c|c|c|}
\hline Variables & Mean & Frequency & Percentage & Standard Deviation \\
\hline $\begin{array}{l}\text { Students' Perception of } \\
\text { Classroom Environ- } \\
\text { ment }_{\text {Total }}\end{array}$ & 185.10 & \multirow{8}{*}{378} & \multirow{8}{*}{100.00} & 29.706 \\
\hline a. Cohesiveness & 28.56 & & & 4.735 \\
\hline b. teacher support & 25.69 & & & 6.037 \\
\hline c. involvement & 24.12 & & & 5.752 \\
\hline d. investigation & 22.96 & & & 6.146 \\
\hline e. task orientation & 29.82 & & & 5.355 \\
\hline f. cooperation & 25.79 & & & 7.326 \\
\hline g. equity & 28.54 & & & 6.318 \\
\hline English Achievement $_{\text {Total }}$ & 38.23 & 378 & 100.00 & 14.753 \\
\hline - Excellent & 86 & 1 & 0.26 & - \\
\hline - Good & 76 & 18 & 4.76 & 5.757 \\
\hline - $\quad$ Average & 62.35 & 34 & 8.99 & 4.631 \\
\hline - $\quad$ Poor & 46.46 & 61 & 16.14 & 4.342 \\
\hline - $\quad$ Very Poor & 30.27 & 264 & 69.84 & 6.217 \\
\hline
\end{tabular}




\subsubsection{Mean Difference of Sdudents' English Achievement Based on Sub-Districts}

The assumption of different district has different students' English achievement is proved to become the fact based on the results of this study and the difference among them was significant with the $\mathrm{F}=10.066$ and the level of significance was $p<.000$. From the 15 sub-districts it is known that the highest students' English achievement was that of the schools in Ilir Barat I sub-district (Mean = 53.83) followed by Bukit Kecil (mean = 48.44), Alang-alang Lebar $($ mean $=46.89)$, Kemuning $($ mean $=42.67)$, Sukarame $($ mean $=39.28)$, Ilir Barat $2($ mean $=37.78)$, Seberang Ulu $2($ mean $=36.44)$, Ilir Timur $1($ mean $=36.00)$, Seberang Ulu $1($ mean $=35.63)$, Kertapati $($ mean $=34.44)$, Ilir Timur $2($ mean $=31.44)$, Kalidoni (mean $=30.11)$, Plaju (mean $=29.22)$, Gandus $($ mean $=28.33$ and the lowest was that of Sako sub-district $($ Mean $=28.11)$. The mean score of the sub-districts total was 38.23. See table 2 .

Table 2. Mean Difference of Students' English Achievement (SEA) Based on Sub-districts

\begin{tabular}{|c|c|c|c|c|}
\hline No. & Sub-districts & Frequency (\%) & Mean & Standard Deviation \\
\hline 1 & Ilir Barat 1 & $36(9.52 \%)$ & 53.83 & 17.743 \\
\hline 2 & Bukit Kecil & $36(9.52 \%)$ & 48.44 & 17.152 \\
\hline 3 & Alang-Alang Lebar & $18(4.76 \%)$ & 46.89 & 14.262 \\
\hline 4 & Kemuning & $18(4.76 \%)$ & 42.67 & 15.170 \\
\hline 5 & Sukarame & $36(9.52 \%)$ & 39.28 & 12.487 \\
\hline 6 & Ilir Barat 2 & $18(4.76 \%)$ & 37.78 & 9.428 \\
\hline 7 & Seberang Ulu 2 & $18(4.76 \%)$ & 36.44 & 12.030 \\
\hline 8 & Ilir Timur 1 & $18(4.76 \%)$ & 36.00 & 10.035 \\
\hline 9 & Seberang Ulu 1 & $54(14.3 \%)$ & 35.63 & 14.164 \\
\hline 10 & Kertapati & $18(4.76 \%)$ & 34.44 & 8.333 \\
\hline 11 & Ilir timur 2 & $36(9.52 \%)$ & 31.44 & 10.803 \\
\hline 12 & Kalidoni & $18(4.76 \%)$ & 30.11 & 7.078 \\
\hline 13 & Plaju & $18(4.76 \%)$ & 29.22 & 8.544 \\
\hline 14 & Gandus & $18(4.76 \%)$ & 28.33 & 6.481 \\
\hline 15 & Sako & $18(4.76 \%)$ & 28.11 & 5.880 \\
\hline & Sub-districts total & $378(100 \%)$ & 38.23 & 14.753 \\
\hline
\end{tabular}

\subsection{Statistical Analysis}

There were three statistical analyses used in this study: (1) the correlation between students' perception of classroom environment (SPCE) and their English achievement (SEA); (2) the contribution of SPCE to SEA, and (3) the difference between SPCE and SEA in terms of gender.

\subsubsection{Correlation between SPCE and SEA}

The result of the correlation between SPCE and SEA can be seen in table 3. Based on this table, it is found that there is a positive significant correlation between students' perception on classroom environment and students' English achievement $(\mathrm{r}=.103 ; \mathrm{p}<.044)$. To strengthen the findings of this study, each aspect of the classroom environment was also correlated to students' English achievement as suggested by Fraser, Fisher, and McRobbie (1996), the inventor of the WIHIC questionnaire. From the result of Pearson Product Moment Analysis, it was found that six aspects of classroom environment did not have any significant correlation to the students' English achievement. Only equity, the last aspect, which significantly correlated to students' English achievement $(r=.107, p<.038)$. Nevertheless, teacher support was almost related significantly to students' English achievement in as much as its probability value was a little bit higher than the level of significance.

Table 3. Summary Statistics of Pearson Product Moment Correlation Coefficient of Students' Perception of Classroom Environment (SPCE) Aspects and Their English Achievement (SEA) $(\mathrm{N}=378)$

\begin{tabular}{lcc}
\hline \multicolumn{1}{c}{ Aspects of SPCE } & Correlation Coefficient $(\mathbf{r})$ & Significant Level $(\mathbf{p}<\mathbf{. 0 5})$ \\
\hline SPCE $_{\text {Total }}$ & $\mathbf{. 1 0 3}$ & $\mathbf{. 0 4 4}$ \\
\hline Cohesiveness & .052 & .314 \\
\hline Teacher Support & .099 & .055 \\
\hline Involvement & .091 & .077 \\
\hline Investigation & .086 & .096 \\
\hline Task Orientation & .089 & .083 \\
\hline Cooperation & .036 & .487 \\
\hline Equity & $\mathbf{. 1 0 7}$ & $\mathbf{. 0 3 8 ^ { * }}$ \\
\hline
\end{tabular}

*Correlation is significant at the 0.05 level (2-tailed) 
Knowing that there was a positive correlation between SPCE ${ }_{\text {Total }}$ and SEA, the analysis was then continued by using regression analysis using Enter method to see whether Students' Perception on Classroom Environment really had a significant influence on students' English achievement. The result of the analysis showed that these seven aspects of classroom environment contributed only $1.5 \%$ to students' English achievement and it was not significant ( $\mathrm{R}=.121$; $\mathrm{R}^{2}=.015 ; \mathrm{F}=.791$; level of significance .595 ). Therefore, it can be concluded that some other unexplained factors which influence students' English achievement more than just classroom environment. This fact revealed that these seven factors of classroom environment, simultaneously, did not correlate significantly to students' English achievement.

However, when the influence of the classroom environment aspects and students' English achievement was analyzed by using stepwise analysis, it showed a slight difference from the previous result using Enter as the method of analysis. The seventh aspect or equity did contribute significantly to students' English achievement $\left(\mathrm{R}=.107, \mathrm{R}^{2}=.011\right.$, Fobtained $=4.318>$ F-table $=2.033, \mathrm{~T}$-obtained $=2.078>\mathrm{T}$-table $=1.96$, and $\mathrm{p}<.038$ ). Therefore, it can be concluded that students' English achievement was partially influenced by equity aspect of classroom environment.

\subsubsection{Mean Difference of SPCE and SEA Based on Gender}

In order to know whether or not gender makes a difference to students' perceptions of their classroom environment and English achievement, Independent Samples T-Test was applied. The result showed that the mean difference between female and male students on their classroom environment was 10.709 and its level of significance was $p=.000$. See table 4. This difference occurred in six out of seven aspects of classroom environment, such as teacher support, involvement, investigation, task orientation, cooperation, and equity.

On the contrary, the analysis of the difference between students' English achievement in terms of gender showed an interesting fact. It was found that the probability value of students' English achievement was higher than the level of significance $(\mathrm{p}=.344)$ which means that there was no significant difference in students' English achievement in terms of gender (mean difference was 1.439). See table 4.

Table 4. Perceptions of Classroom Environment (SPCE) and Students' English Achievement (SEA) Based on Gender

\begin{tabular}{ccccc}
\hline Variables & T & Df & Significant Level & Mean Difference \\
\hline SPCE & 3.558 & 376 & .000 & 10.709 \\
\hline SEA & .948 & 376 & .344 & 1.439 \\
\hline
\end{tabular}

\section{3 Discussion}

That this study shows low English achievement of the eighth graders of state junior high schools in Palembang has invited us to crosscheck the obtained score with the minimum standard score for English subject which is 75 . It is identified $97.35 \%$ of the students has failed in achieving the minimum score set by their own schools. Moreover, if these students are going to participate in the national examination held by the government, it is assumed that it would result in the failure because none of these students has reached the score set by the government.

What has been going on with these students? When the data were collected, these students had already learned English for almost eight years, but why they could not achieve the targetted score in learning this language. We assume that this is not merely the students' fault, but also the teachers' as educators and the government's as the policy makers.

Then, what is wrong with the teaching and learning process and policies? Logically, if the teachers had thoroughly followed the curriculum and implemented it in accordance with what they had already planned, they would have had been successful in guiding and helping their students. Furthermore, there is a possibility that these students' achievement also has a strong connection with the quality of the teachers of English. Having seen the result of their competency test (Uji Kompetensi Guru) which is prominent as the basis for receiving teacher qualification status, it would be reasonable if it is assumed that this nightmare happens because the result of the teachers' competency test was not good either, that is only 42.25 out of 100 (Srie, 2013). In addition, the government has also played an important role in making these students fail. It is also assumed that South Sumatra Department of Education has not fully monitored what is going on in each school in the area.

Furhermore, why in this present study only Ilir Barat I sub-district has the highest English achievement is probably due to the conduciveness this area is for learning. This area is an education district. There are quite many schools available in this area, beginning from kindergarten up to higher education level. This condition may have encouraged many citizens to be educated.

That this study also reveals that among the seven aspects of classroom environment, only equity is proved to have significant influence on students' English achievement is probably due to students' feeling that they have been treated equally and have had full attention from the teachers. This finding coincides with the result of the study conducted by Otami, Ampiah, and Anthony-Krueger (2012) which focuses on the importance of the implementation of equity in the biology class. In other words, a descrepency in equity will surely lead to students' inability to do optimally to achieve the best in every lesson, including English and eventually will lessen the students' motivation and influence the result of their study. These findings support the issue of the importance of the equity in the educational world suggested by 
United Nation Educational Scientific and Cultural Organization (UNESCO) (2010) and Organization for Economic Cooperation and Development (OECD) (2008). These organizations which are well-known for their sayings, 'education for all and lifelong learning,' believe that male and female students should have the same opportunity in learning, chance in pursuing their dreams, and right to participate in every activity conducted in the schools or classes. It is often claimed that if every student is treated equally, no matter what the gender is, it will help him or her succeed in his or her lessons as is proved in this study. This has strengthened the finding that there is no difference between male and female students in their English achievement.

However, why does gender prove to be significantly different in perceptions of their classroom environment in which female students has better perceptions of classroom environment in almost all the seven aspects, probably indicate that gender also plays an important role in classroom management. It might happen because females are usually better in language classes (read Kim, et al., 2000) and also Baker (2007). They identified that males love science or math classes while female students usually think highly of the relationship and interaction among other students. Therefore, according to Gurian and Stevens (2004), it is important for them to have as many friends as they can to do various activities which suits their personalities. With English classes, as reported in their study, a good atmosphere has helped girl students develop their characteristics better. Meanwhile, male students do not really keen on activities which require them to read, speak, and or listen inasmuch as their brain is better in working with symbols, abstractions, and picture. Unfortunately, such various strategies which require them to be fully involved are not used in most of the schools in Palembang. Diem, Yusfardiyah, Koniaturrohmah, and Lismalayani (2013) found that $62 \%$ junior and senior high school teachers admit that they still use lecturing method in their teaching and learning process. In summary, if the study had been done in math or science classroom environment and also considering students' needs or learning styles using various teaching strategies, the results would have been different.

\section{Conclusions and Implications}

Based on the results of the study, three conclusions can be drawn. First, classroom environment is found correlated positively to students' English achievement. Since it shows that there is a positive correlation, it can be concluded that the more conducive classroom environment as perceived by the students, the better their English achievement will be. Unfortunately this study reveals that most of junior high school students in Palembang still have low English achievement, that is below the average level. Second, gender is also proved to significantly influence students' perceptions of their classroom environment. Female students has better perceptions than do male students of their classroom environment but not for their English achievement. Third, although classroom environment only has small contribution to students' English achievement, one of its aspects, equity, is proved to be an influential factor on students' English achievement.

Therefore, some implications may be underlined and considered by English teachers, students, and future researchers. First, teachers of English may not easily feel satisfied with the condition of their school. They should think of the way how to enhance their classroom environment so that, conducive teaching and learning process will always be maintained. They should also treat their students' equally since this aspect is proved to have significant contribution to the betterment of students' achievement. It is also better if the teachers also pay attention to this aspect when they interact with the students in the classroom. Let them participate fully without considering their difference in gender. In addition, future researchers, are suggested to do the study about whether or not all levels of schools either in Palembang or South Sumatera have already treated their students equally as suggested by UNESCO and OECD. Therefore, it is encouraged that they do not merely rely on the questionnaire but also do some observation to crosscheck the students' answers to the questionnaire with the real condition in schools. By doing so, it will add to the value of accuracy of the data.

\section{References}

Badan Akreditasi Nasional--Sekolah/Madrasah (BAN-S/M). (2009). Instrumen pengumpulan data dan informasi pendukung akreditasi SMP/MTs. Retrieved from http://www.ban-sm.or.id/uploads/3_DATAPendukung SMP-MTs.pdf

Badan Standar Nasional Pendidikan (BNSP). (2006). Panduan penyusunan kurikulum tingkat satuan pendidikan dasar dan menengah. Jakarta: BSNP.

Baker, H. (2007). Gender differences in the classroom. Retrieved from http://faculty.tnstate.edu/ bchristian1/bakerpres.ppt

Chua, S. L., Wong, A. F. L., \& Chen, D. T. (2009). An instrument for investigating Chinese language learning environments in Singapore secondary schools. Australian Journal of Educational \& Developmental Psychology, 9, 5364. Retrieved from http://www.newcastle.edu.au/Resources/Research\%20Centres/SORTI/Journals/ AJEDP/Vol\%209 /v9-chua-et-al.pdf

Diem, C. D. (1988). The relationships among teacher self-concept, multicultural education, and effectiveness in teaching reading as perceived by American and Indonesian classroom teachers. (Unpublished Dissertation), Ball State University, Muncie, Indiana, USA.

Diem, C. D. (1998). Teacher self concept and teacher effectiveness as perceived by teachers of English and students of senior high schools. Jurnal Ilmu Pendidikan, 5(3), 154-166. 
Diem, C. D., Yusfardiyah, Koniaturrohmah, \& Lismalayani. (2013). Implementation of school-based curriculum as perceived by secondary school teachers of English. A paper presented at the 60th TEFLIN International Conference, August 27-29, in Jakarta.

Diknas Provinsi Sumatera Selatan. (2010). Hasil akreditasi sekolah/madrasah badan akreditasi propinsi sekolah/madrasah (BAP-S/M) provinsi Sumatera Selatan SMP/MTs kota Palembang tahun 2005-2010. Palembang: BAP S/M Sum-Sel.

Diknas Provinsi Sumatera Selatan. (2010). Nilai rata-rata ujian nasional mata pelajaran bahasa Inggris tahun ajaran 2009-2010. Palembang: Diknas Sum-Sel.

Fitriani, E., Diem, C. D., \& Saripudin, A. (2007). The correlation between self-concept and reading comprehension achievement of students of private universities in Palembang. Lingua, 4(1), 1-19.

Fraser, B. J., \& Chionh, Y. H. (2009). Classroom environment, self-esteem, achievement, and attitudes in geography and mathematics in Singapore. International Research in Geographical and Environmental Education, 18(1). Retrieved from http://www.tandfonline.com/doi/abs/10.1080/10382040802591530

Goh, S. C., \& Fraser, B. J. (1998).Teacher interpersonal behavior, classroom environment and student outcomes in primary mathematics in Singapore. Learning Environments Research, 1, 199-299.

Gurian, M., \& Stevens, K. (2004). With boys and girls in mind. Educational Leadership, 62(3), 21-26. Retrieved from http://www.ascd.org/publications/educational-leadership/nov04/vo162/num03/with-boys-and-girls-in-mind.aspx

Hoang, T. N. (2008). The effects of grade level, gender, and ethnicity on attitude and learning environment in mathematics in high school. International Electronic Journal of Mathematics Education, 3(1), 47-59. Retrieved from http://www.iejme.com/012008/d3.pdf

Jimbon. (2009, November 13). Sertifikasi guru tidak tepat sasaran. KOMPAS.com. Retrieved from http://edukasi.kompas.com/read/2009/11/13/07473414/sertifikasi .guru.tidak.tepat.sasaran

Khine, M. S. (2001). Using the WIHIC questionnaire to measure the learning environment. Teaching \& Learning, 22(2), 54-61.

Kim, H. B., Fisher, D. L., \& Fraser, B. J. (2000). Classroom environment and teacher interpersonal behavior in secondary science classes in Korea. Evaluation and Research in Education, 14, 3-22.

Klem, A. M., \& Connell, J. P. (2004). Relationship matter: Linking teacher support to student engagement and achievement. Journal of School Health, 74(7), 262-273.

Margianti, E. S., Fraser, B. J., \& Aldridge, J. M. (2001, December). Investigating the learning environment and students' outcomes at the university level in Indonesia. Paper Presented at the Annual Meeting of the Australian Association of Research Education (AARE), Fremantle, Western Australia. Retrieved from http: //www.aare.edu.au/01 pap/mar01668.htm.

Miller, A., \& Cunningham, K. (2006).Classroom environment. Retrieved from http://www.education.com/ reference/article/classroom- environment/

Organization for Economic Co-operation and Development. (2008). Ten steps to equity in education. OECD. Retrieved from http://www.oecd.org/dataoecd/21/45/39989494.pdf

Otami, D. C., Ampiah, J. G., \& Anthony-Krueger, C. (2012). Factors influencing elective science students' perception of their biology classroom environment in low and high academic achieving schools in the central region of Ghana International Journal of Research Studies in Education, 1(1), 35-46. Retrieved from http://www.consortiacademia.org/index.php/ijrse /article/view/12/12

Purwadi, D. (2011, April 26). Kecurangan saat UN. Bangka Pos. Retrieved from http://bangka.tribunnews.com/mobile/index.php//2011/04/26/kecurangan-saat-un

Sarwono, S. W. (2006). Psikologi remaja. Jakarta: PT. Raja GrafindoPustaka.

Slameto. (2003). Belajar dan faktor-faktor yang mempengaruhinya. Jakarta: Rineka Cipta.

SMAN 2 Palembang. (2011). Daftar nilai kelas XII IPA 1-2 dan XII IPS 2-3 tahun pelajaran 2010/2011. Palembang: SMAN 2.

SMPN 1 Palembang. (2011). Laporan nilai akhir semester ganjil tahun pelajaran 2011/2012 kelas IX2-IX5. Palembang: SMPN1.

Srie. (2013, February 26). Hasil UKA dan UKG kompetensi guru lebih buruk dari laporan Aljazeera? [Web log post]. Retrieved from http://www.srie.org/2013/02 /hasil-uka-dan-ukg-kompetensi-guru-lebih.html

Sun-Geun, B., \& Hye-Jeong, C. (2002). The relationship between students' perceptions of classroom environment and their academic achievement in Korea. Asia Pacific Education Review, 3(1), 125-135. Retrieved from http://eri.snu.ac.kr/aper/pdf/3-1/11-11.pdf

Treagust, D. F., \& Wahyudi. (2004). The status of science classroom learning environment in Indonesian lower secondary schools. Learning Environments Research, 7(1), 43-63. doi: 10.1023/B:LERI.0000022282.48004.18

Universitas Sriwijaya. (2008). Buku pedoman Fakultas Keguruan dan Ilmu Pendidikan Universitas Sriwijaya. Indralaya: Author.

Yunizar. (2011, May 6). Pengumuman kelulusan UN 2011 tingkat SMP/MTs di beberapa daerah Indonesia [Web log post]. Retrieved from http://yunizar.com/ 